\title{
EFEKTIVITAS APLIKASI UAS ONLINE DALAM MENJAGA MUTU PERKULIAHAN DI MASA PENDEMI COVID-19
}

\author{
R A Purba \\ Program Studi Manajemen Informatika, Politeknik Unggul LP3M, Medan \\ Email: ramenantonovpurba@gmail.com
}

\begin{abstract}
ABSTRAK
Kehadiran Covid-19 menyebabkan seluruh elemen harus merubah kebiasaanya. Terlebih sesuai dengan arahan pemerintah dengan mewajibkan kerja dari rumah, belajar dari rumah, serta ibadah dari rumah. Ujian Akhir Semester (UAS) merupakan cara untuk mengevaluasi tingkat pemahaman mahasiswa. Harus diselenggarakan secara baik dan berkualitas. Tidak bisa asal-asalan. Pengembangan teknologi sebagai upaya menjamin kualitas dan indepedensi perjalanan UAS yang dilakukan telah berjalan.Penelitian bertujuan melihat efektivitas aplikasi UAS online dalam menjaga mutu perkuliahan di masa pendemi Covid-19. Untuk melihat apakah aplikasi yang dibangun sesuai dengan fungsi, kesesuaian, kegunaan, kehandalan, efisiensi kinerja, serta kemudahan pemeliharaan. Aplikasi UAS online dibangun dengan mempergunakan bahasa pemrograman berbasis website dan database berbasis server. Metode pada penelitian ini menggunakan $R \& D$. Variabel penelitian Mahasiswa Politeknik Unggul LP3M sejumlah 29 mahasiswa. Aplikasi UAS yang dibangun memudahkan serta mampu meningkatkan mutu perkuliahan di masa pandemi Covid-19. Aplikasi UAS yang dibangun memiliki 3 otorisasi pengguna antara lain admin, dosen, serta mahasiswa. Sesuai dengan hasil test, aplikasi UAS dikatakan memenuhi kelayakan. Diantaranya nilai test aplikasi sejumlah $85.33 \%$ (Sangat Pantas Sekali) serta skor Coefficient Alpha sejumlah 0.87 (Sangat Baik Sekali). Didapati jika aplikasi UAS online yang dibangun mampu menjaga mutu perkuliahan di masa pandemi Covid-19. Perkuliahan di situasi pandemi Covid-19 dapat berjalan sesuai dengan harapan dengan adanya aplikasi yang dibangun sesuai dengan tahapan-tahapan standar.
\end{abstract}

Kata kunci: UAS Online, Pandemi Covid-19, LP3M, R\&D

\begin{abstract}
The presence of Covid-19 causes all elements to change their habits. Especially by government regulations which require working from home, studying from home, and worshipping from home. Final Semester Examina-tion (UAS) is a way to evaluate the level of understanding of students. It must be administered correctly and with good quality. You cannot be careless. The development of technology to ensure the quality and independence of UAS trips that has been carried out. The research aims to see the effectiveness of the online UAS application in maintaining the quality of lectures during the Covid-19 epidemic. To see whether the application is built by function, suitability, usability, reliability, performance efficiency, and ease of maintenance. The online UAS application is built using a website-based programming language and a server-based database. The method in this study uses $R \& D$. The research variables of the Politeknik Unggul LP3M Students were 29 students. The UAS application built made it more accessible and improved the quality of lectures during the Covid-19 pandemic. The UAS application that was built has three user authorizations, including admins, lecturers, and students. By the test results, the UAS application is said to meet the eligibility. Among them, the application test score is $85.33 \%$ (Very Appropriate), and the Cronbach Alpha value is 0.87 (Excellent). The online UAS application built was able to maintain the quality of lectures during the Covid-19 pandemic. Studies in the Covid-19 pandemic situation can run as expected with applications built according to standard stages.
\end{abstract}

Keywords : Final Examination, Covid-19 pandemic, LP3M, R\&D 


\section{PENDAHULUAN}

Hadirnya Covid-19 menyebabkan seluruh elemen harus merubah kebiasaanya. Terlebih sesuai dengan arahan pemerintah yang mengharuskan kerja dari rumah, belajar dari rumah, serta ibadah di rumah [1]. Belajar dari rumah merupakan domain instansi pendidikan. Di awal kebijakan ini diumumkan, banyak instansi pendidikan yang kelimpungan. Disebabkan belum tersedianya sarana pra sarana, infrastruktur, dan instrumen yang dapat dijadikan acuan. Selain itu, potensi manusia yang bertugas mengembangkan dalam hal ini dosen juga mengalami kebingungan guna memulai pembelajaran ketika tatap muka dihentikan [2]. Tetapi proses mendidik harus tetap berjalan meskipun tatap muka tidak diijinkan. Solusi yang dipakai yakni menggunakan kecanggihan teknologi informasi berbasis jaringan. Seluruh instansi pendidikan tinggi menggunakan sistem online dan menggunakan sistem informasi yang dibangun khusus untuk mengakomodir seluruh proses pembelajaran. Ada pula yang mengkombinasikan media sosial dan sistem informasi dalam pembelajaran [3]. Intinya pembelajaran tetap berjalan sesuai dengan kurikulum yang telah disusun, hanya saja jika selama ini dilakukan secara tatap muka di kelas, berganti ruang menjadi tatap muka di media [4].

Untuk mengevaluasi apakah pembelajaran yang dilakukan oleh dosen dipahami oleh mahasiswa, dilakukan test dalam bentuk ujian. Artinya, meskipun pembelajaran dilakukan dengan sistem, kualitas pembelajaran harus tetap dijaga [5]. Instansi pendidikan tinggi dalam menjalankan program pendidikan diawasi oleh instansi yang ada diatasnya. Bahkan secara berkala harus menyusun dokumen kinerja dan evaluasi sesuai dengan apa yang dilakukan untuk mendapatkan pengakuan dalam bentuk Akreditasi [6]. Oleh karenanya kualitas harus dijaga dengan melakukan evaluasi yang bentuk evaluasinya dapat diakses semua pihak, transparan, terukur, dan dapat didokumentasikan. Sehingga setiap mahasiswa yang diuji, sesuai dengan mata kuliah yang ditetapkan dapat dilihat hasilnya ujiannya secara lengkap dan jelas [7].

Mutu pendidikan sesuai dengan instruksi pemerintah melalui Kemendikbud Dikti harus pula secara berkala di audit. Sudah ada ditetapkan pihak yang mengaudit dalam bentuk Audit Mutu Internail (AMI). Proses audit dilakukan oleh auditor yang telah mendapatkan pelatihan dan sertifikat sebagai ijin untuk melakukan audit mutu [8]. Sehingga ketika perkuliahan dilakukan secara online (tidak tatap muka langsung) wajib dijaga kualitasnya. UAS sebagai bagian dari komponen guna mengevaluasi taraf pemahaman mahasiswa harus diselengarakan secara baik dan berkualitas. Tidak bisa asal-asalan [9]. Pengembangan teknologi sebagai upaya menjamin kualitas dan indepedensi perjalanan UAS yang dilakukan telah berjalan. Aplikasi yang telah berjalan tersebut diharapkan dapat berfungsi sesuai dengan apa yang telah disepakati oleh seluruh pihak manajemen dengan tujuan guna menjaga mutu perkuliahan. Ketika melakukan UAS sikap tidak jujur tentu harus dihindarkan. Selain itu kesiapan mahasiswa dalam mengikuti UAS dengan fasilitas aplikasi yang telah dibangun tentu harus diperhatikan dan menjadi kewajiban mahasiswa untuk bersiap [10].

Aplikasi yang merupakan produk yang dibangun dengan menggunakan bahasa pemrograman dalam implementasinya tentu memiliki standarisasi. Standarisasi terkait kelayakan dan indepensi aplikasi itu sendiri [11]. Terlebih situasi pandemi Covid-19 yang tidak mengijinkan tatap muka, peranan aplikasi menjadi sangat penting dan sentral. Aplikasi menjadi tumpuan serta harapan agar perjalanan perkuliahan tetap dapat berjalan dengan baik. Karenanya aplikasi yang dipergunakan haruslah memenuhi kriteria sesuai dengan acuan ketetapan. Karena aplikasi diharapkan dapat menjembatani korelasi antara dosen dan mahasiswa [12]. Tak hanya itu, aplikasi sangat diharapkan untuk meminimalkan kesalahan seperti ketika ujian dilakukan secara langsung menggunakan kertas ujian. Aplikasi juga membantu dosen dalam melakukan penilaian. Juga membantu dosen melakukan pengurutan hasil ujian mahasiswa berdasarkan urutan nilai tertinggi. Aplikasi harus teliti melebihi dosen ketika melakukan pemeriksaan kertas jawaban. Aplikasi juga menjadi tumpuan penyimpanan hasil evaluasi ujian mahasiswa. Selain itu aplikasi memiliki konsistensi yang tinggi sesuai dengan apa yang telah distandarkan kedalam sistem tersebut. Jadi kerusakan kertas ujian yang sering terjadi ketika ujian sebelum hadirnya Covid-19 tidak terjadi [13].

Dalam membangun aplikasi UAS tentu ada tahapan yang dilakukan, mengacu kepada tahapantahapan yang baku untuk membangun sebuah aplikasi. Tahapan-tahapan yang ada jangan sampai dilewati, karena ketika dilewati, maka akan ada kekuatiran akan standarisasi dari aplikasi yang dibangun [14]. Tahapan-tahapan baku wajib diikuti karena telah sesuai dengan standar yang ditentukan. Aplikasi yang baik merupakan aplikasi yang langkah-langkah membangunnya tidak menyalahi aturan atau telah disesuaikan dengan mekanisme yang dianjurkan. Mengingat aplikasi yang ingin dibangun merupakan aplikasi yang akan dimanfaatkan untuk menjaga mutu perkuliahan melalui aplikasu UAS online yang akan dibangun. Adapun acuan yang dimaksud seperti pada gambar 1 yakni [15] : 


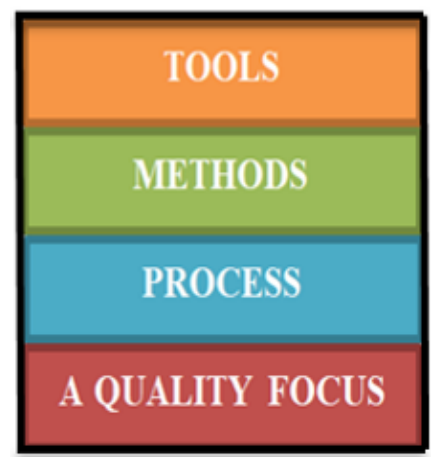

Gambar 1. Tahapan Dalam Membangun Aplikasi

Tools merupakan bahasa pemrograman yang dimanfaatkan untuk membangun aplikasi. Karena aplikasi yang dibangun hakikatnya online, maka bahasa pemrograman yang dimanfaatkan juga yang mampu mengakomodir aplikasi online seperti web [16]. Selain itu dilengkapi dengan penyimpanan data yang juga dibangun dengan aplikasi dengan sistem server. Methods merupakan tahapan sasaran ketika membangun aplikasi. Prosedur apa yang akan dipergunakan. Process adalah langkah dalam membangun aplikasi. Sesuai dengan pemikiran si pembuat aplikasi. A Quality Focus merupakan yang terutama, dimana tahapan ini merupakan inti pemikiran. Dengan inti pemikiran, si pembuat program akan memiliki pikiran apa saja yang akan ditampilkan di aplikasi yang dibangunnya [17].

Meskipun situasi pandemi Covid-19 masih belum memperlihatkan kapan akan berakhir, mutu perkuliahan haruslah tetap terjaga. UAS yang merupakan ujian akhir yang dilaksanakan di setiap akhir semester harus dilaksanakan sesuai dengan ketentuan yang telah disepakati. Meskipun pelaksanannya dilaksanakan melalui sistem yang telah dibangun, tahapan-tahapan pengerjaannya hingga tahapan penilaiannya harus dilaksanakan secara objektif. Seperti [18] dalam penelitiannya menyimpulkan aplikasi yang dibangun guna dijadikan sebagai media pembelajaran di masa pandemi Covid-19 harus tetap mampu untuk mempertahankan mutu perkuliahan. Jangan sampai karena situasional tidak ideal, mutu perkuliahan juga ikut menjadi tidak ideal. [19] dalam penelitiannya mengatakan, aplikasi yang baik pastilah akan menghasilkan produk yang baik. Artinya mutu perkuliahan yang menjadi acuan untuk dijaga, akan dapat berjalan dengan baik ketika aplikasi yang dipergunakan juga baik.

Sesuai dengan pemaparan yang telah dijelaskan, penelitian ini akan bertujuan guna menaikkan mutu UAS di tengah pandemi Covid-19. Juga bertujuan sebagai jaminan mutu aplikasi yang dibangun sesuai dengan fungsi, kesesuaian, kegunaan, kehandalan, efisiensi kinerja, serta kemudahan pemeliharaan. Covid-19 yang merupakan bencana global, jangan sampai menyebabkan mutu perkuliahan melalui pelaksanaan UAS menjadi ikut turun.

\section{METODE}

Metode penelitian menggunakan R\&D. Dimana ada produk yang dibangun serta akan dilihat kebermanfaatannya [20]. Untuk membangun produk dalam hal ini aplikasi UAS, dipergunakan konteks Rational Unified Process (RUP). Adapun tahapan RUP seperti gambar 2 berikut [21] :

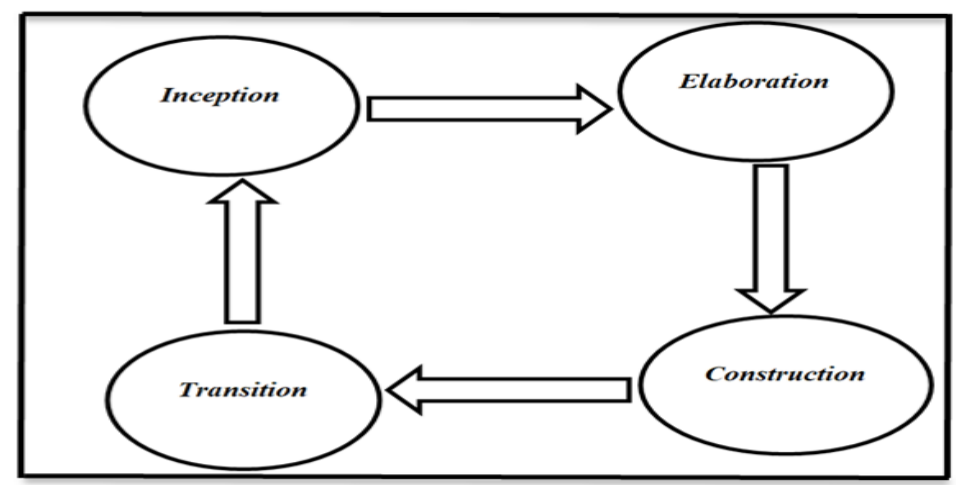

Gambar 2. Tahapan Rational Unified Process (RUP) 
Untuk Inception merupakan tahapan yang dilakukan guna menggambarkan model aplikasi yang diinginkan sesuai dengan kebutuhan. Elaboration merupakan tahapan untuk menggambarkan desain dari aplikasi yang akan dibangun. Construction merupakan tahapan membangun aplikasi sesuai dengan desain yang telah digambar sebelumnya. Membangun aplikasi dengan mempergunakan bahasa pemrograman sesuai dengan keinginan. Kemudian transition merupakan tahapan implementasi atau memberikan aplikasi kepada pengguna untuk dipergunakan dan dilihat apakah sudah sesuai atau masih ada kekurangan.

Untuk variabel penelitian yakni Mahasiswa Politeknik Unggul LP3M untuk UAS mata kuliah Analisa Perancangan Sistem Informasi. Untuk test aplikasi fokus kepada standarisasi kualifikasi aplikasi berbasis website. Guna mengetahui sejauh mana kemaksimalan dari aplikasi yang dibangun, akan dibagikan lembar isian untuk diisi oleh mahasiswa setelah menggunakan aplikasi UAS yang telah dibangun. Menu pada lembar jawaban yakni Sangat Bertentangan Sekali (STS), Sangat Bertentangan (SB), Sedikit Bertentangan (SB), Pantas (P), serta Sangat Pantas Sekali (SSS). Untuk skala menggunakan Likert. Berikut tabel 1 berisi lembar isian :

Tabel 1. Simulasi Daftar Pertanyaan Isian

\begin{tabular}{lcc}
\hline Urutan & Poin Tanya & Kesimpulan (STS, SB, SB, P,SSS) \\
\hline Ke-1 & UAS jadi lebih Efektif & STS, SB, SB, P, SSS \\
Ke-2 & Lebih Semangat & STS, SB, SB, P, SSS \\
Ke-3 & Aplikasi bermanfaat & STS, SB, SB, P, SSS \\
Ke-4 & Aplikasi memudahkan & STS, SB, SB, P, SSS \\
Ke-5 & Aplikasi praktis & STS, SB, SB, P, SSS \\
Ke-6 & Mudah dipelajari & STS, SB, SB, P, SSS \\
Ke-7 & Puas dengan aplikasi & STS, SB, SB, P, SSS \\
Ke-8 & Aplikasi konsisten & STS, SB, SB, P, SSS \\
\hline
\end{tabular}

Kemudian guna mendapatkan rerata persentase hasil test dipergunakan rumus seperti berikut :

$$
\text { P Skor }=\frac{\text { Nilai Seluruh }}{i \times r \times 5} \times 100 \%
$$

Catatan :

Nilai Seluruh : Seluruh paparan isian pertanyaan mahasiswa i : Kuantitas isian pertanyaan

r

: Kuantitas mahasiswa yang mengisi

Setelah itu akan dikonversi sesuai dengan kaidah Likert dengan skala 5. Bentuknya seperti tabel 2 berikut :

Tabel 2. Konversi 5 Skala Kaidah Likert

\begin{tabular}{lcl}
\hline Urutan & Capaian $(\%)$ & \multicolumn{1}{c}{ Status } \\
\hline Ke-1 & $0-21$ & Sangat Bertentangan Sekali \\
Ke-2 & $22-41$ & Sangat Bertentangan \\
Ke-3 & $42-61$ & Sedikit Bertentangan \\
Ke-4 & $62-81$ & Pantas \\
Ke-5 & $82-100$ & Sangat Pantas Sekali \\
\hline
\end{tabular}

Untuk alur UAS di Politeknik Unggul LP3M memiliki aliran tahapan mulai dari perencanaan hingga kepada pengumpulan nilai UAS. Di mana diawali dengan memberikan informasi kepada dosen tentang waktu pelaksanaan UAS, sehingga dosen yang pertemuannya masih belum memenuhi segera melakukan pertemuan pengganti. Dosen juga diminta untuk membuat soal yang dilengkapi dengan jawabannya dan menyerahkan dokumen tersebut kepada bagian akademik yang merupakan panitia ujian. Untuk lengkapnya alur UAS yang ada di Politeknik Unggul LP3M dapat dilihat dengan urutan seperti gambar 3 berikut : 


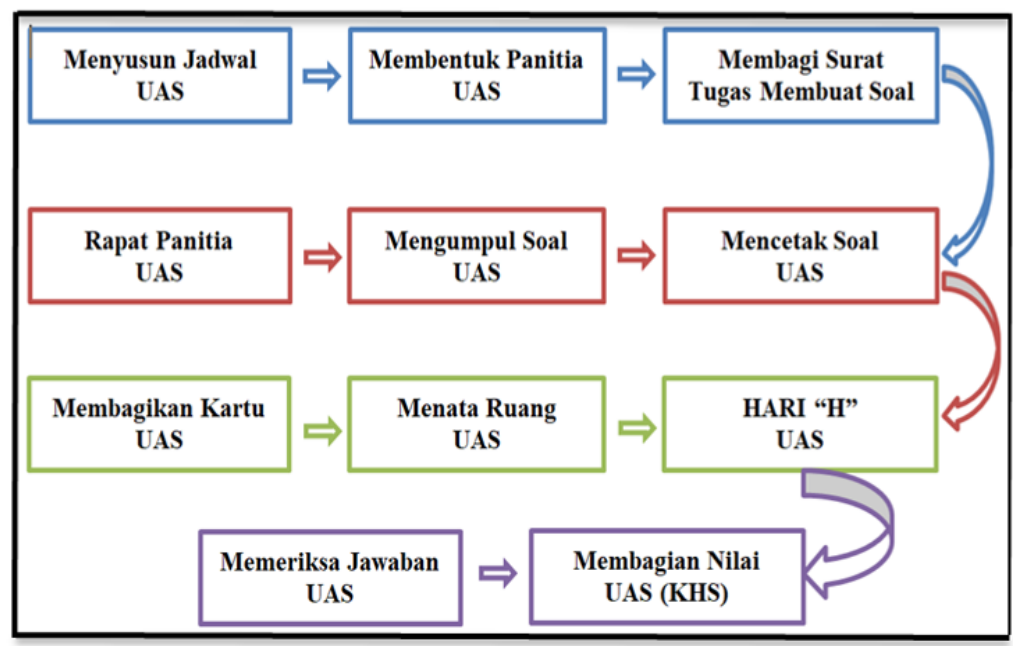

Gambar 3. Alur Pelaksanaan UAS

\section{HASIL DAN PEMBAHASAN}

Untuk aplikasi UAS yang dibangun melibatkan beberapa unsur pengguna sesuai dengan tingkatannya. Masing-masing pengguna memiliki otorisasinya masing-masing. Dimana masing-masing pengguna memiliki privasi yang tidak akan bisa tertukar karena dibedakan dalam user name masingmasing pengguna. Adapun yang akan menjadi pengguna dalam aplikasi UAS yang dibangun antara lain Admin, Dosen, dan Mahasiswa. Admin bertugas memonitoring dan mengontrol seluruh aktivitas yang berjalan di aplikasi. Dosen memiliki tugas sesuai dengan tupoksinya yaitu membuat soal, memeriksa jawaban mahasiswa, dan memberikan penilaian terhadap hasil UAS yang dikerjakan oleh mahasiswa. Mahasiswa sendiri memiliki otoritas di aplikasi antara lain Login atau masuk ke aplikasi UAS, kemudian memilih soal sesuai dengan jadwal UAS, kemudian menjawab setiap soal yang ada. Untuk otorisasi ini digambarkan dalam bentuk diagram ditampilkan pada gambar 4 berikut :

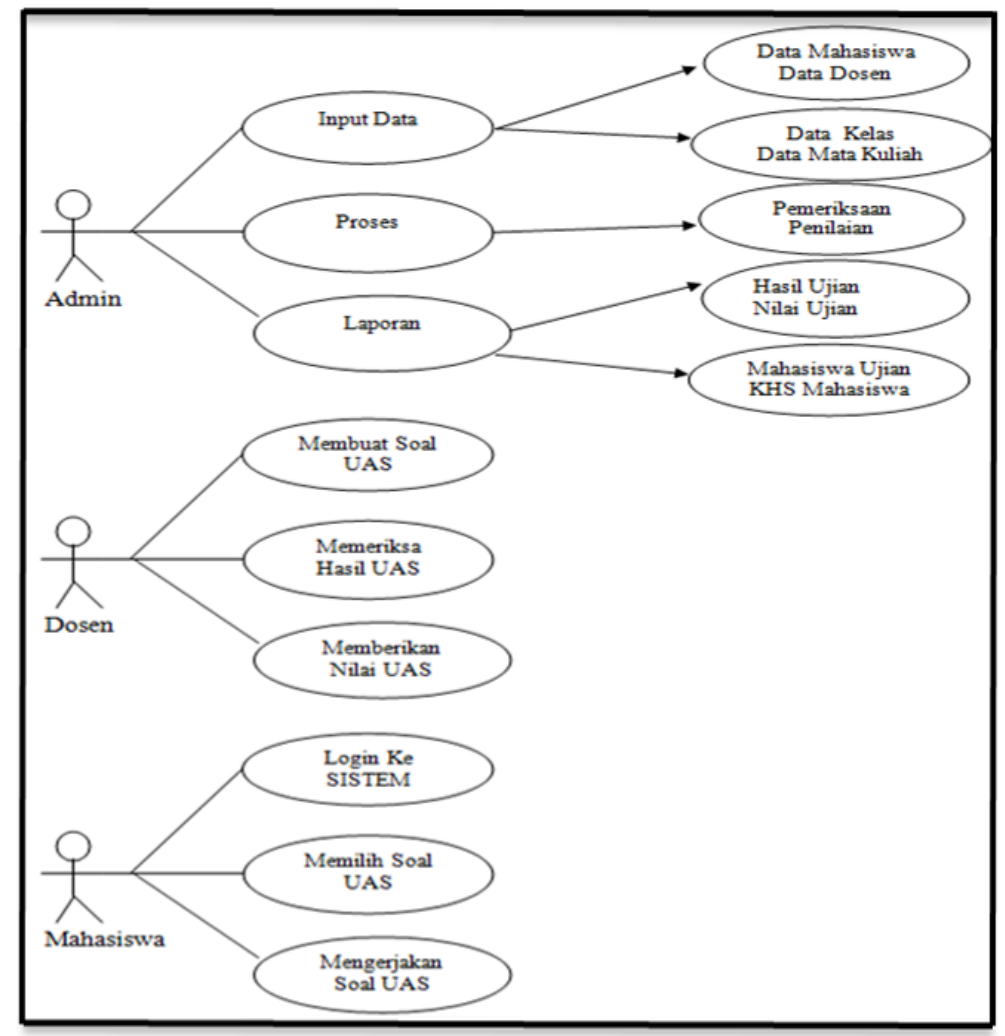

Gambar 4. Diagram Otorisasi Aplikasi 
Berikutnya adapun tampilan dari aplikasi yang dibangun, pertama-tama ketika aplikasi dijalankan akan tampil menu untuk memasukkan username dan password. Username dan password sesuai dengan otorisasi masing-masing. Apabila sebagai mahasiswa makan akan memiliki username dan password yang diperuntukkan untuk mahasiswa. Demikian pula untuk dosen mapun panitia. Masing-masing akan memiliki username dan password. Adapun tampilan menunya dapat dilihat seperti gambar 5 :

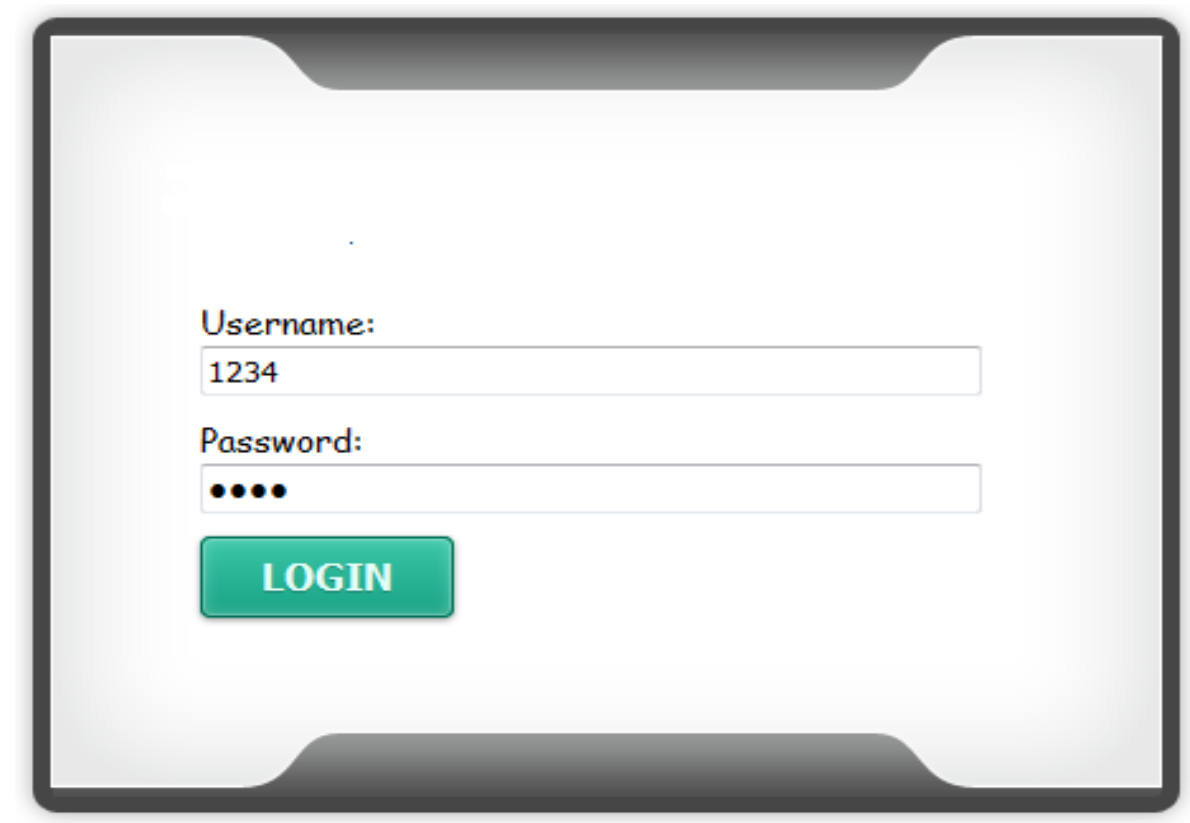

Gambar 5. Tampilan Awal Aplikasi

Setelah memasukkan username dan password, akan tampil menu aplikasi untuk memilih makul mana yang bakal diujiankan. Makul yang akan diujiankan sesuai dengan daftar mata kuliah yang ada di kurikulum sesuai dengan semester yang berjalan seperti jadwal pelaksanaan UAS yang telah disusun. Dengan demikian setiap pihak sesuai dengan otorisasinya masing-masing dapat mengakses menu aplikasi sesuai dengan apa yang menjadi kebutuhannya. Adapun tampilannya seperti ditampilkan gambar 6 berikut :

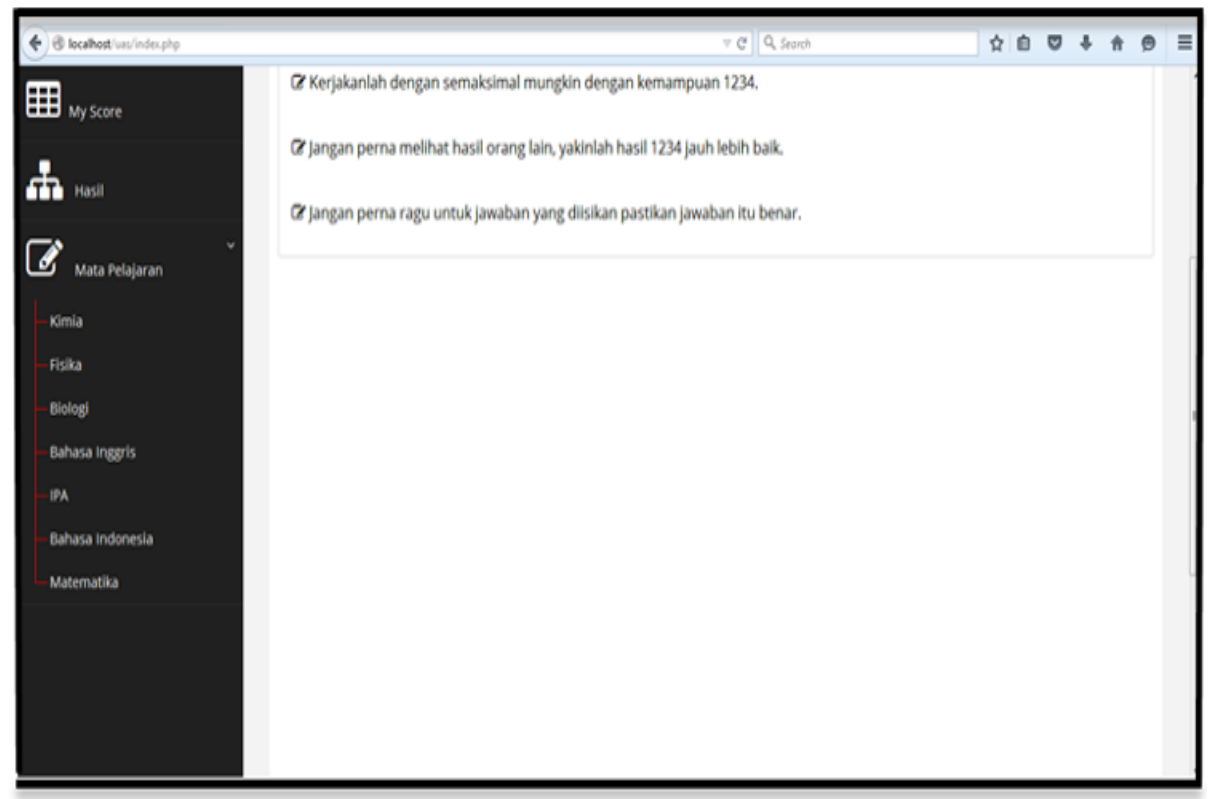

Gambar 6. Tampilan Memilih Mata Kuliah 
Kemudian terdapat menu untuk mengisikan soal yang merupakan otoritas dari admin aplikasi UAS. Melalui menu ini, admin akan memasukkan soal UAS per mata kuliah sesuai dengan jadwal ujian yang telah disusun. Admin dapat pula menugaskan dosen untuk melakukan tugas ini. Tergantung bentukan kepanitiaan yang telah ditetapkan sebelumnya. Bentuknya seperti gambar 7 berikut :

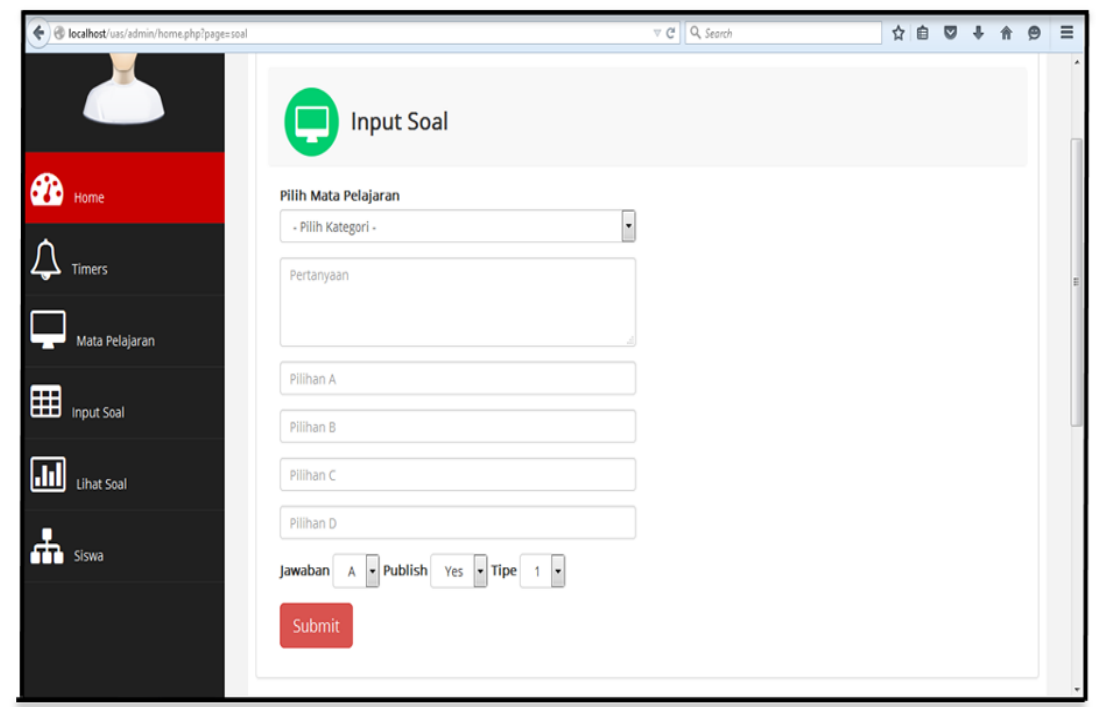

Gambar 7. Tampilan Memasukkan Soal Ujian per Mata Kuliah

Berikutnya aplikasi juga dapat menampilkan nilai sesuai dengan hasil UAS yang dilakukan oleh mahasiswa. Sehingga dapat langsung diperoleh nilai UAS begitu jawaban telah selesai diisikan pada sistem. Mahasiswa akan langsung dapat melihat apakah dia lulus dalam mata kuliah yang di UAS kan atau tidak lulus. Meskipun hasil final tetap pada pengumuman yang akan dilakukan oleh admin maupun dosen. Adapun tampilannya seperti gambar 8 :

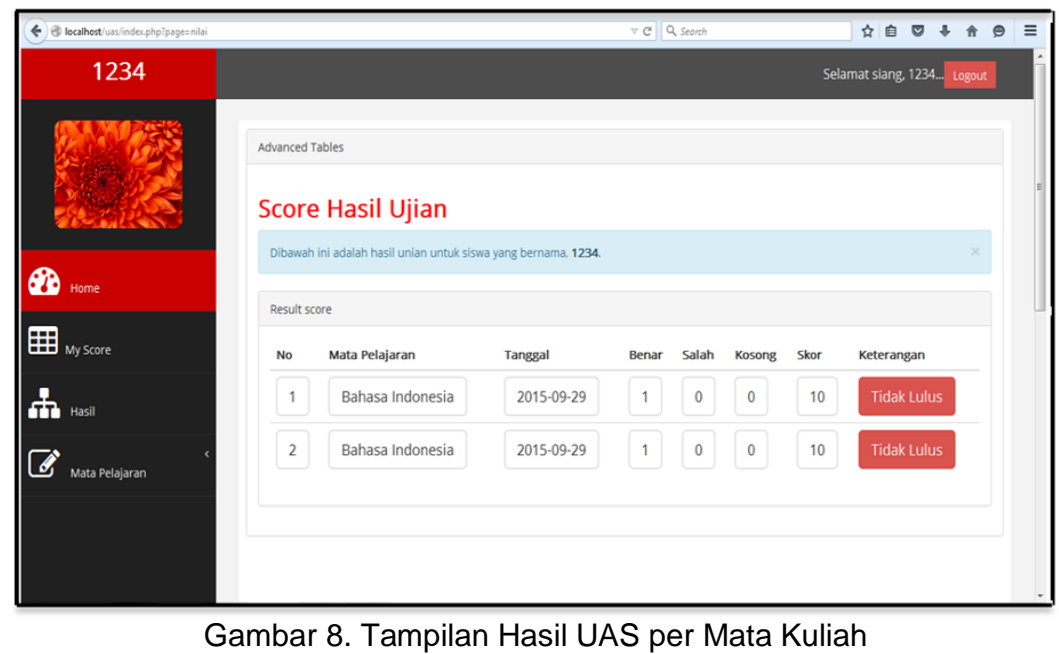

Setelah aplikasi dipergunakan, maka dilakukan test untuk melihat apakah aplikasi yang dibangun memang sesuai dan direkomendasikan untuk dipergunakan dalam menghadapi UAS di masa pandemi Covid-19. Seperti yang telah disebutkan sebelumnya jika test terhadap aplikasi dilakukan menggunakan konteks menjawab pertanyaan yang telah disediakan. Ada 30 soal pertanyaan yang ditanyakan kepada pengguna aplikasi. Dalam penelitian ini ada 29 mahasiswa yang 
mempergunakan aplikasi dan diberikan lembaran isian untuk memberikan jawaban setelah selesai menggunakan aplikasi UAS. Berikut ditampilkan hasil jawaban mahasiswa seperti tabel 3 :

Tabel 3. Hasil Test Aplikasi

\begin{tabular}{lccc}
\hline Urutan & Jlh Pertanyaan & Total & Nilai Maksimum \\
\hline Ke-1 & 30 & 132 & 150 \\
Ke-2 & 30 & 125 & 150 \\
Ke-3 & 30 & 131 & 150 \\
Ke-4 & 30 & 132 & 150 \\
Ke-5 & 30 & 128 & 150 \\
Ke-6 & 30 & 120 & 150 \\
Ke-7 & 30 & 130 & 150 \\
Ke-8 & 30 & 121 & 150 \\
Ke-9 & 30 & 125 & 150 \\
Ke-10 & 30 & 131 & 150 \\
Ke-11 & 30 & 132 & 150 \\
Ke-12 & 30 & 133 & 150 \\
Ke-13 & 30 & 128 & 150 \\
Ke-14 & 30 & 130 & 150 \\
Ke-15 & 30 & 123 & 150 \\
Ke-16 & 30 & 135 & 150 \\
Ke-17 & 30 & 145 & 150 \\
Ke-18 & 30 & 139 & 150 \\
Ke-19 & 30 & 123 & 150 \\
Ke-20 & 30 & 134 & 150 \\
Ke-21 & 30 & 124 & 150 \\
Ke-22 & 30 & 104 & 150 \\
Ke-23 & 30 & 125 & 150 \\
Ke-24 & 30 & 129 & 150 \\
Ke-25 & 30 & 133 & 150 \\
Ke-26 & 30 & 132 & 150 \\
Ke-27 & 30 & 124 & 150 \\
Ke-28 & 30 & 120 & 150 \\
Ke-29 & 30 & 124 & 150 \\
\hline Total & & 3712 & 4350 \\
\hline & & &
\end{tabular}

Sesuai dengan nilai test di tabel 3 didapatkan nilai total sejumlah 3712 . Untuk jumlah persentase nilai test dilakukan uji sebagai berikut :

$$
P \text { Skor }=\frac{3712}{4350} \times 100 \%=85,33 \%
$$

Didapatkan nilai test dengan persentase $85,33 \%$. Mengacu ke hasil konversi di tabel 2 maka aplikasi UAS dikatakan Sangat Layak. Berdasarkan pernyataan Gliem dalam [22], dapat pula diperoleh interpretasi nilai Coefficient Alpha. Dengan bentuk interpretasi pada tabel 4 berikut :

Tabel 4. Interpretasi Nilai Coefficient Alpha

\begin{tabular}{cl}
\hline Coefficient Alpha & Konsistensi Internal \\
\hline$\alpha \geq .10$ & Baik Sekali \\
$.10>\alpha \geq .9$ & Baik Saja \\
$.9>\alpha \geq .8$ & Layak Diterima \\
$.8 \alpha \geq .7$ & Dipertanyakan
\end{tabular}




$$
6>\alpha \quad \text { Ditolak }
$$

Sesuai dengan result test aplikasi yang telah dilakukan diatas, dapat pula didapatkan kategori grade coefficient alpha dari aplikasi UAS yang telah di test. Adapun kategori grade didapatkan dengan menggunakan aplikasi statistik. Sehingga didapatkan nilai yang kemudian dikategorikan kedalam grade sesuai dengan interpretasi yang telah ditetapkan di tabel 4. Bentuknya dapat diperlihatkan seperti gambar 9 berikut :

$$
\begin{aligned}
& \text { Reliability Analysis } \\
& \text { Call: psych::alpha }(x=\text { Data }) \\
& \text { raw_alpha std.alpha G6(smc) average_r S/N } \\
& \begin{array}{lllll}
0.87 & 0.87 & 1 & 0.18 & 6.7
\end{array}
\end{aligned}
$$

Gambar 9. Tampilan Test Coefficient Alpha

Dengan nilai sejumlah 0.87 , sesuai dengan interpretasi pada tabel 4 , maka test yang telah dilakukan terhadap aplikasi UAS dikategorikan Sangat Baik Sekali. Dengan demikian aplikasi UAS online yang dibangun dapat menjaga mutu perkuliahan di masa pandemi Covid-19. Sehingga dapat ditarik sebuah asumsi bahwa media aplikasi yang hakikat kerjanya online dapat dimanfaatkan sebagai media perkuliahan di situasi seperti pandemi Covid-19 [23]. Media aplikasi yang dibangun dengan tahapan-tahapan yang baik akan menghasilkan produk aplikasi yang dapat menjaga mutu perkuliahan meskipun situasi dalam kondisi tidak normal [24]. Aplikasi berbasis online sangat tepat dipergunakan pada situasi tidak standar seperti pada masa pandemi Covid-19 yang belum dapat dipastikan kapan akan berakhir [25].

Mutu merupakan komponen penting yang akan menjadi parameter nilai bagi institusi pendidikan. Semakin baik mutu dijaga, akan semakin baik pula penilaian terhadap institusi pendidikan tersebut [26]. Aplikasi menjadi salah satu solusi ketika tatap muka tidak dapat dilaksanakan. Karenanya aplikasi yang ada harus dibangun dengan tahapan-tahapan yang sesuai dengan standarisasi. Sehingga aplikasi yang dihasilkan dapat dimanfaatkan secara maksimal. Untuk mendukung kinerja aplikasi, sumber daya manusia tentu harus diselaraskan pula. Dengan demikian seluruh perjalanan perkuliahan, apakah pembelajaran, pemberian tugas, hingga ke pelaksanaan UAS dapat berjalan dengan baik dan sesuai dengan apa yang telah dicanangkan oleh unsur manajemen institusi pendidikan tinggi [27]. UAS merupakan salah satu parameter evaluasi untuk melihat tingkat pemahaman mahasiswa terhadap mata kuliah yang dipelajarinya. Dengan menggunakan aplikasi yang interaktif serta mudah untuk dipergunakan, seluruh tahapan UAS akan berjalan dengan baik serta mampu menjaga mutu perkuliahan [28].

\section{SIMPULAN DAN SARAN}

Aplikasi UAS yang dibangun memudahkan serta mampu meningkatkan mutu perkuliahan di masa pandemi Covid-19. Aplikasi UAS yang dibangun memiliki 3 otorisasi pengguna antara lain admin, dosen, serta mahasiswa. Sesuai dengan hasil test, aplikasi UAS dikatakan memenuhi kelayakan. Diantaranya nilai test aplikasi sejumlah $85.33 \%$ (Sangat Pantas Sekali) serta nilai Coefficient Alpha sejumlah 0.87 (Sangat Baik Sekali).

Adapun yang menjadi saran yakni kedepan akan sangat baik jika aplikasi yang dibangun juga mengakomodir pelaksanaan Ujian Semester Pendek (SP). Agar lebih menarik dan interaktif, sekaligus menghadirkan suasana santai, dapat pula disisipkan bentuk multimedia dalam selingan ketika aplikasi dioperasikan. Berikutnya kemampuan dan komposisi aplikasi ditingkatkan, sehingga memungkinkan untuk mengisi dan menampilkan ragam gambar dalam 1 soal ujian yang sama. Sehingga akan lebih menambah dan meningkatkan usaha mahasiswa ketika mengikuti ujian. Untuk dapat diakses di mana saja serta kapan saja, kedepan aplikasi dapat dikombinasikan dengan perangkat mobile dengan sistem android.

\section{DAFTAR PUSTAKA}

[1] R. A. Purba, "Kampus Merdeka Dalam New Normal: Risiko Dan Kesempatan," Kampus 
Merdeka Seri 3 Mengen. Risiko Sist. Kampus Merdeka di Masa New Norm., p. 95.

[2] E. Sudarmanto et al., Pengembangan Budaya Akademik. Yayasan Kita Menulis, 2021.

[3] R. Faslah and A. Haris, "Perencanaan strategis sistem informasi," J. ELTIKOM J. Tek. Elektro, Teknol. Inf. dan Komput., vol. 1, no. 1, pp. 31-38, 2017.

[4] R. A. Purba et al., Pengantar Media Pembelajaran. Yayasan Kita Menulis, 2020.

[5] S. Susilowati and T. Hidayat, "Rancang Bangun Sistem Informasi Ujian Online (Studi Kasus Pada SMAN 58 Jakarta)," J. Tek. Komput., vol. 4, no. 1, pp. 30-36, 2018.

[6] M. B. Legowo and B. Indiarto, "Model Sistem Penjaminan Mutu Berbasis Integrasi Standar Akreditasi BAN-PT dan ISO 9001: 2008," J. RESTI (Rekayasa Sist. dan Teknol. Informasi), vol. 1, no. 2, pp. 90-98, 2017.

[7] D. Darmaji, A. Supriyanto, and A. Timan, "Sistem Penjaminan Mutu Internalsekolah Untuk Meningkatkan Mutu Lulusan," JMSP (Jurnal Manaj. dan Supervisi Pendidikan), vol. 3, no. 3, pp. 130-136, 2019.

[8] E. Y. Nasution, I. Sailah, and I. Hermadi, "Strategi Lembaga Layanan Pendidikan Tinggi Wilayah I Sumatera Utara dalam Peningkatan Mutu Perguruan Tinggi Swasta," J. Penjaminan Mutu, vol. 7, no. 1, pp. 10-17, 2021.

[9] U. V. Wardina, N. Jalinus, and L. Asnur, "Kurikulum Pendidikan Vokasi Pada Era Revolusi Industri 4.0," J. Pendidik., vol. 20, no. 1, pp. 82-90, 2019.

[10] R. A. Purba et al., Teknologi Pendidikan. Yayasan Kita Menulis, 2020.

[11] J. Simarmata et al., Elemen-Elemen Multimedia untuk Pembelajaran. Yayasan Kita Menulis, 2020.

[12] R. Sanjaya, 21 Refleksi Pembelajaran Daring di Masa Darurat. SCU Knowledge Media, 2020.

[13] H. Rasyida, "Efektivitas Kuliah Daring Di Tengah Pandemik," 2020.

[14] R. A. Purba et al., Aplikasi Teknologi Informasi: Teori dan Implementasi. Yayasan Kita Menulis, 2020.

[15] Y. Amrozi, S. D. K. Wardani, and R. Ramadhan, "Quo Vadis Pengembangan Rekayasa Perangkat Lunak," J. Teknol. Terap. G-Tech, vol. 3, no. 2, pp. 237-244, 2020.

[16] L. D. Herliandry, N. Nurhasanah, M. E. Suban, and H. Kuswanto, "Pembelajaran pada masa pandemi covid-19," JTP-Jurnal Teknol. Pendidik., vol. 22, no. 1, pp. 65-70, 2020.

[17] A. Mauluddin and M. Aditya, "Pengembangan Perangkat Lunak Pemilihan Ketua Umum Berbasis Web Pada Organisasi IPMKN," Inf. (Jurnal Inform. dan Sist. Informasi), vol. 10, no. 1, pp. 103-122, 2018.

[18] S. N. Y. B. Bhakti, "Pengaruh Media Pembelajaran Online Dalam Pemahaman Dan Minat Belajar Siswa Pada Konsep Pelajaran Fisika," Orbita.Jurnal Has. Kajian, Inovasi, dan Apl. Pendidik. Fis., vol. 6, no. November, pp. 248-251, 2020.

[19] G. Sakkir, S. Dollah, and J. Ahmad, "Favorite E-Learning Media in Pandemic Covid-19 Era," J. Stud. Guru Dan Pembelajaran, vol. 3, no. 3, pp. 480-485, 2020.

[20] S. Agus and B. S. Pegy, "Pengembangan Perangkat Lunak E-Learning Pada SMA Negeri 15 Palembang Dengan Metode Rational Unified Process." STMIK Palcomtech, 2019.

[21] D. Sudaryono, "Metodologi Riset di Bidang TI," Yogyakarta Andi, 2015.

[22] T. A. Ghaffur, "Analisis Kualitas Sistem Informasi Kegiatan Sekolah Berbasis Mobile Web Di Smk Negeri 2 Yogyakarta," Elinvo (Electronics, Informatics, Vocat. Educ., vol. 2, no. 1, pp. 94101, 2017.

[23] R. Y. U. Hanifah, "Pengaruh Pembelajaran Daring terhadap Minat Belajar Siswa pada Masa COVID 19," Edukatif J. Ilmu Pendidik., vol. 2, no. 3, pp. 236-240, 2020.

[24] G. A. I. Utami, N. Sugihartini, and D. S. Wahyuni, "Efektivitas Media E-Learning Dengan Model Blended Learning Pada Mata Pelajaran Geografi Kelas X Di Sma Negeri 2 Banjar," J. Pendidik. Teknol. dan Kejuru., vol. 18, no. 1, pp. 22-31, 2021.

[25] U. V. Krismadinata et al., "Blended Learning as Instructional Model in Vocational Education: Literature Review," Univers. J. Educ. Res., vol. 8, no. 11B, pp. 5801-5815, 2020.

[26] T. A. P. C. T. Harjanto, "Pengaruh Mutu Pembelajaran Online Dan Tingkat Kepuasan Mahasiswa Terhadap Hasil Belajar Saat Pandemi Covid19," Pendidik. Teknol. dan Kejuru., vol. 17, no. 2, pp. 188-197, 2020.

[27] R. A. Purba, "The Effectiveness Combination of Blended Learning and Flipped Classroom with Edmodo as a Digital Media Innovation for Learning From Home," J. Educ. Technol., vol. 5, no. 3, 2021.

[28] E. D. M. U. J. M. O. Pandango, "Pengaruh Pembelajaran Daring Berbantuan Laboratorium Virtual Terhadap Minat dan Hasil Belajar Kognitif Fisika," Jartika J. Ris. Teknol. dan Inov. Pendidik., vol. 3, no. 2, pp. 351-359, 2020, doi: 10.36765/jartika.v3i2.288. 